Vol.. 6, No. 1, 2020

Doi: https://doi.org/10.24198/cosmogov.v6i1.25736

http://jurnal.unpad.ac.id/cosmogov/index

\title{
TERMINAL MANAGEMENT POLICY AND PASSENGER ACCESSIBILITY AT CICAHEUM BUS TERMINAL BANDUNG, WEST JAVA
}

\author{
Fajar Tri Sakti \\ Universitas Islam Negeri Sunan Gunung Djati (SGD) Bandung, \\ Jl. A.H. Nasution No.105, Cipadung, Cibiru, Bandung City, West Java, Indonesia \\ Correspondence Email: fadjartrisakti@uinsgd.ac.id
}

Submitted: January 17, 2020, Reviewed: May 02, 2020, Accepted: May 06, 2020

\begin{abstract}
This research is based on the main problem, namely: accessibility of the Bandung Cicaheum terminal is not optimal. This is thought to be caused by terminal management not yet being implemented. The approach used in this research is terminal management to the accessibility of case study passengers at the Cicaheum terminal. The research method used in this study uses qualitative methods with a case study. On this study, the researcher emphasizes more on investigations to understand social problems, based on respondents' detailed views of the problem. The results showed that the dimension of terminal management had not been carried out especially the planning dimension. The change of authority mandates that type A terminals that serve between cities and provinces become the authority of the central government. It has been three years since the mandate of the Law has been carried out over the function of authority, especially the elements of Personnel, Funding, Facilities and Infrastructure, and Documents (P3D). Research findings since the 2019 Budget Year Bandung City Government through the Department of Transportation has no longer allocated the Cicaheum terminal budget. Likewise, accessibility dimension, especially the intensity factor (density) of land use which is no longer suitable with the current conditions.
\end{abstract}

Keywords: authority, Personnel, Funding, Facilities and Infrastructure, and Documents (P3D).

\begin{abstract}
ABSTRAK
Penelitian ini didasarkan pada masalah pokok yaitu: aksesibilitas terminal cicaheum Kota Bandung tidak optimal. Hal ini diduga, disebabkan oleh pengelolaan terminal belum dilaksanakan. Pendekatan yang digunakan dalam penelitian ini adalah pengelolaan terminal terhadap aksesibilitas penumpang studi kasus pada terminal Cicaheum. Metode penelitian yang digunakan dalam penelitian ini menggunakan metode kualitatif dengan pendekatan studi kasus. Dalam penelitian ini, peneliti lebih menekankan pada penyelidikan untuk memahami masalah sosial, berdasarkan pada pandangan responden yang terperinci tentang masalah. Hasil penelitian menunjukan bahwa dimensi pengelolaan terminal belum dilaksanakan terutama dimensi perencanaan. Perubahan kewenangan yang mengamanatkan bahwa terminal tipe A yang melayani antar kota dan provinsi menjadi kewenangan pemerintah pusat. Sudah tiga tahun amanat Undang-undang belum dilaksanakan alih fungsi kewenangan terutama unsur Personel, Pendanaan, Sarana dan Prasarana, serta Dokumen (P3D). Temuan penelitian sejak Tahun Anggaran 2019 Pemerintah Kota Bandung melalui Dinas Perhubungan sudah tidak mengalokasikan lagi anggaran terminal cicaheum. Demikian pula dimensi aksesibilitas terutama faktor intensitas (kepadatan) guna lahan yang sudah tidak sesuai lagi dengan kondisi saat ini.
\end{abstract}

Keywords: kewenangan, Personel, Pendanaan, Sarana dan Prasarana, serta Dokumen (P3D). 
Vol.. 6, No. 1, 2020

Doi: https://doi.org/10.24198/cosmogov.v6i1.25736

http://jurnal.unpad.ac.id/cosmogov/index

\section{BACKGROUND}

Bandung City as one of the metropolitan cities in Indonesia has an area of $167.31 \mathrm{KM}^{2}$, consisting of 30 Districts, 151 Sub-Districts. The population according to Statistics Indonesia (BPS) data reached 2.5 million by 2018 . The number consisted of 1.26 million men and 1.24 million women. Geo-political and geostrategic aspects, Bandung is one of the 14 major metropolitan cities. Bandung is the capital of West Java Province with the largest population in Indonesia. The city of Bandung has a geographical appeal since the colonial era. In addition, the city of Bandung is known for having several highquality universities, which stood since long ago compared to other cities.

The consequences of cities with the title as a big city, of course, in addition to having strengths and opportunities, there will be weaknesses and threats. One of the threats felt at this time is traffic jams. Bandung city based on the latest survey of the Asian Development Bank (ADB), currently including the most congested cities in Indonesia. At the Asian level, Bandung depends on the order of the 14 most congested cities. Meanwhile, DKI Jakarta depends on the 17th place, then Surabaya on the 20. The survey conducted by ADB approved 278 cities which were translated from 45 countries. According to the Deputy Mayor of Bandung, congestion occurs due to the increasing number of residents during the daytime which can reach 3.7 million people. There are 1.2 million people outside the city of Bandung who is doing activities in the city of Bandung so that traffic jams will be one thing that will happen.

Congestion occurs one of the causes is the number of vehicles that are not balanced with the availability of the road. Public transportation is the best solution, but until now people are still reluctant and reluctant to use public transportation. The community still chooses private vehicles, both cars and motorbikes, with far more effective considerations, traffic jams are a common thing faced by the community.

Table 1. Number of Non-Public 4 and 2 Wheeled Vehicles for BPKB by Bandung Service Branch (Pajajaran, Kawaluyaan, Soetta)

\begin{tabular}{ccccccc}
\hline Revenue Service Unit & \multicolumn{2}{c}{ Four-wheel vehicle } & \multicolumn{2}{c}{ Motorcycle } & \multicolumn{2}{c}{$\begin{array}{c}\text { Four-Wheel and Two } \\
\text { Wheel Vehicles }\end{array}$} \\
\hline & $\begin{array}{c}\text { Non-public } \\
\text { vehicle }\end{array}$ & $\begin{array}{c}\text { Public } \\
\text { vehicle }\end{array}$ & $\begin{array}{c}\text { Non-public } \\
\text { vehicle }\end{array}$ & $\begin{array}{c}\text { Public } \\
\text { vehicle }\end{array}$ & $\begin{array}{c}\text { Non-public } \\
\text { vehicle }\end{array}$ & $\begin{array}{c}\text { Public } \\
\text { vehicle }\end{array}$ \\
Bandung City Padjadjaran & 147.752 & 5.584 & 323.718 & & 610.230 & 5.584 \\
Bandung City Kawaluyaan & 164.406 & 6.024 & 462. & 597.447 & 6.025 \\
Kota Bandung City Soetta & 138.377 & 3.475 & 478 & 493.937 & 3.475 \\
\hline Total & $\mathbf{4 5 0 . 5 3 5}$ & $\mathbf{1 5 . 0 8 3}$ & $\mathbf{1 . 1 4 1 . 7 5 6}$ & $\mathbf{1 . 7 0 1 . 6 1 4}$ & $\mathbf{1 5 . 0 8 4}$ \\
\hline & Source: West Java Province BPS processed, 2019.
\end{tabular}

The data above shows that there is an imbalance in the number of non-public vehicles and public vehicles; this is thought to be a trigger for traffic congestion, so the Bandung City Government must seriously develop strategies, policies and programs in overcoming this phenomenon. Next is the data on the number of public transportation in Bandung City in 2017 based on vehicle class. 
Vol.. 6, No. 1, 2020

Doi: https://doi.org/10.24198/cosmogov.v6i1.25736

http://jurnal.unpad.ac.id/cosmogov/index

Table 2. The Number of Public Transportation in Bandung City in 2017

\begin{tabular}{lc}
\hline \multicolumn{1}{c}{ Vehicle class } & Number of units \\
\hline Large Public Bus & 1.464 \\
Medium Public Bus & 101 \\
Small Public Bus & 5.356 \\
Bus Not Public & 330 \\
City transport & 5.521 \\
Taxi & 1.387 \\
\hline
\end{tabular}

Source: Bandung City Transportation Agency, 2019

Noting the data above, the Bandung City Government must strive to make a breakthrough in innovation so that the mindset of the community can change from being happy to use private vehicles to enjoy using public transportation. Of course, the change in mindset must be accompanied by good faith and concrete actions of the government as an element of public service in providing excellent services, especially services in the field of public transportation. Public transportation and terminal management are included in the affairs of government in the field of transportation, which is listed in the Law of the Republic of Indonesia Number: 23 of 2014 concerning Regional Government. 4 (four) sub-affairs in the transportation sector include Traffic and Road Transportation (LLAJ), shipping, aviation, railroad.

Based on the division of government affairs in the transportation sector, one of the mandates and those relevant to this research is the management of type A passenger terminal is a National authority, management of type $B$ passenger terminal is Provincial authority, and management of type $\mathrm{C}$ passenger terminal is Regency/City authority. Thus the Cicaheum Terminal and the Leuwipanjang terminal that were once the authority of the
City of Bandung, but since the enactment of the Law of the Republic of Indonesia Number: 23 of 2014 became the National Authority.

A terminal to be made must be in accordance with its functions and uses and must be in accordance with spatial planning and regional zoning. The main function of the terminal is to provide good service. In this regard (Suparman, 2017) mentions that service is considered quality if it does not cause complaints from the community it serves. The quality of service itself is related to the concept of customer satisfaction (Customer Satisfaction). Public services in the field of public transportation in addition to providing public transportation modes both bus and non-bus are connected to several places both in the city of Bandung and outside the city of Bandung. In addition to modes of transportation that are no less important are public transportation terminal facilities that are representative, easily accessible (accessibility) by prospective passengers.

Cicaheum Terminal is currently felt to be inadequate, in addition to the location of the area which is no longer strategic, along with the rapid development of the city, it also impacts on the accessibility of potential passengers who are reluctant and reluctant to come to the 
Vol.. 6, No. 1, 2020

Doi: https://doi.org/10.24198/cosmogov.v6i1.25736

http://jurnal.unpad.ac.id/cosmogov/index

terminal. Prospective passengers choose to wait outside the terminal or wait in their area of residence to be passed by the bus in accordance with the route, or prospective passengers simply come to the respective bus pool.

Table 3. Recapitulation of Buses and Passengers Arriving and Departing

\begin{tabular}{clcccc}
\hline \multirow{2}{*}{ No } & \multirow{2}{*}{ Month } & \multicolumn{2}{c}{ Arrival } & \multicolumn{2}{c}{ Departure } \\
\cline { 2 - 6 } & & Bus & Passenger & Bus & Passenger \\
\hline 1 & January & 5.334 & 29.156 & 5.273 & 42.189 \\
2 & February & 4.4 .78 & 21.835 & 4.4 .97 & 34.837 \\
3 & March & 5.255 & 27.833 & 5.221 & 39.696 \\
4 & April & 4.950 & 27.467 & 5.064 & 45.109 \\
5 & May & 4.721 & 24.294 & 4.723 & 38.607 \\
6 & June & 5.779 & 40.519 & 5.861 & 69.382 \\
7 & July & 5.412 & 32.931 & 5.346 & 48.046 \\
8 & August & 5.210 & 29.132 & 5.235 & 49.969 \\
9 & September & 4.902 & 26.250 & 4.797 & 37.555 \\
10 & October & 5.109 & 27.665 & 5.050 & 38.679 \\
11 & November & 4.821 & 27.848 & 4.916 & 42.158 \\
12 & December & 5.386 & 31.097 & 5.415 & 62.447 \\
\hline \multicolumn{2}{r}{ Total } & $\mathbf{6 1 . 3 5 7}$ & $\mathbf{3 4 6 . 0 2 7}$ & $\mathbf{6 1 . 3 9 8}$ & $\mathbf{5 4 8 . 6 7 4}$ \\
\hline
\end{tabular}

Source: UPT Terminal, 2019

The existence of the bus fleet at the Cicaheum terminal is also said to be volatile because the number of available buses often exceeds the demand of the people inside the terminal so that many buses prefer to look for passengers outside the terminal rather than inside the terminal. This causes the realization of terminal retribution revenue sometimes cannot reach the target.

Table 4. Target and Realization of Retribution Revenues

\begin{tabular}{cccc}
\hline No & Year & Amount & Target \\
\hline 1 & 2015 & 1.525 .286 .000 & 1.479 .456 .000 \\
2 & 2016 & 1.615 .361 .000 & 1.479 .456 .000 \\
3 & 2017 & 1.274 .567 .500 & 1.479 .456 .000 \\
4 & 2018 & 1.111 .833 .000 & 1.479 .456 .000 \\
5 & 2019 & 323.664 .000 & P3D handover to the Central Government \\
\hline
\end{tabular}

Cicaheum Terminal, aside from being a public service facility for the land transportation sector, also plays a role in supporting regional revenues through user charges by setting targets that do not burden the terminal management, in this case, the priority public service functions. The accessibility of prospective passengers at the Cicaheum terminal is no longer sufficient, in addition to the problem of managing the terminal at the moment in the status quo position because the transition of authority that was once the authority of the City of Bandung has turned into national authority.

In the Organizational Legal Order (HOT) there are many stages that must be carried out which will certainly have implications for P3D (Personnel, Funding, Facilities and Infrastructure and Documents. The central issue of several research issues being considered, the 
Vol.. 6, No. 1, 2020

Doi: https://doi.org/10.24198/cosmogov.v6i1.25736 http://jurnal.unpad.ac.id/cosmogov/index

terminal management is something that is very important and fundamental in the effort to achieve the accessibility of prospective passengers in the Bandung City Cicaheum Terminal, according to Thomas R. Dye, public policy is what the government chooses to do or does not work through. which actually must be done by the government (Agustino, 2006).

Easton was quoted by Wahab as saying that public policy is "the relationship of government units to its environment" (between relationships that take place between government units or units and their environment). Likewise, according to Wilson who formulated public policy as follows: "The actions, objectives, and pronouncements of government on particular matters, the step thy take (or fail to take) to implement them, and the explanations they give for what happens (or does not happen) "(actions, objectives, and statements of the government regarding certain specific problems, steps that have been or are being taken (or failed to be taken) to be implemented, and the explanations given by them what that has happened or not happened (Wahab, 2012).

In addition, Anderson, quoted from Widodo, interpreted the public policy as a response from the political system to the demands or claims and supports that flowed from the environment.

On the basis of this understanding can be found elements contained in public policy as stated by Anderson which include, among others, the following:

1. Policies always have a purpose or are oriented towards a specific goal.
2. The policy contains the actions or patterns of action of government officials.

3. The policy is what the government actually does and not what it intends to do.

4. Public policies are positive (a government action on a particular problem) and negative (the decision of government officials not to do something).

From here we can put public policy as management of achieving national goals. Thus, the essence of public policy is as follows: (1) Public policy is easy to understand because its meaning is the things done to achieve national goals. (2) Public policy is easy to measure because its size is clear namely the extent to which progress in achieving the goals has been taken.

\section{Terminal Management}

Management is a term used in management science in terms of the etymology of management derived from the word "manage" (to manage) and usually refers to the process of taking care or handling something to achieve goals (Adisasmita, 2011).

Management is the control and utilization of all resource factors according to which a planner is needed to complete a particular work goal. The term management is the same as management, where management is part of the management process because in it must be considered about a good work process, organizing a job, directing and supervising, so that what is expected can be done well. 
Vol.. 6, No. 1, 2020

Doi: https://doi.org/10.24198/cosmogov.v6i1.25736 http://jurnal.unpad.ac.id/cosmogov/index

According to Adisasmita (2011), management is not only carrying out an activity but is a series of activities that include management functions, such as planning, implementation and supervision to achieve goals effectively and efficiently.

\section{Passenger Accessibility}

Accessibility is the ease of someone in reaching a location. Accessibility is also interpreted as a measure of comfort or convenience regarding the way land use locations interact with each other and 'easy' or 'difficult' locations is achieved through the transportation network system (Tamim, 2000).

Some claim that accessibility can be expressed with distance. If one place is close to another place, it is said that accessibility between the two places is high. Conversely, if the two places are very far apart, accessibility between the two is low. So, different land uses must have different accessibility because land-use activities are spread out in space unevenly (heterogeneously).

Sheth \& Sisodia said that accessibility is the extent to which customers are able to readily acquire and use the product. It has two dimensions: availability and convenience (Ikhsan, 2016). This means that accessibility is the extent to which the public or customers as consumers can easily obtain and use products. Accessibility has two dimensions, namely: (1) Availability, shown by factors such as supply relative to demand, the extent to which products are stored in storage, related to products and services. (2)
Convenience, indicated by factors such as the time and effort required to obtain the product, the ease with which the product can be found in and various locations, packaging in a convenient size.

Several factors affect the level of accessibility. According to Miro (2009), these factors include:

1. The travel time factor. The travel time factor is very dependent on the availability of transportation infrastructure and reliable transportation systems, for example, a quality road network and guaranteed fleet that is ready to serve at any time.

2. Travel cost/cost factor. Travel costs play a role in determining whether or not the destination is easy to reach because unreachable travel costs result in people (middle and lower classes) being reluctant or even unwilling to travel.

3. The factor of intensity (density) of land use, the density of activities on a plot of land that has been filled with a variety of activities will affect the distance of various activities and indirectly it also increases the level of ease of achieving goals.

\section{METHOD}

In this study, researchers used qualitative methods. The researcher chose to use qualitative research because in this study the researcher put more emphasis on investigations to understand social problems, based on respondents' detailed views of the problem. Qualitative methods 
Vol.. 6, No. 1, 2020

Doi: https://doi.org/10.24198/cosmogov.v6i1.25736

http://jurnal.unpad.ac.id/cosmogov/index

depart from data mining in the form of respondents' views in the form of their detailed or original stories, which are then interpreted so as to create concepts as findings.

Creswell (2012) in Sugiyono (2018) states that: "Qualitative evaluation is a means for exploring and understanding the meaning of individuals or groups ascribe to a social or human problem. The process of research involves emerging questions and procedures: collecting data in the participant 'setting; analizyng the data inductively, building from particular to general themes; and making interpretations of the meaning of data. The final written report has a flexible writing structure "

According to Creswell (2015), there are five approaches in qualitative research, namely narrative, phenomenology, ethnography, case studies, and grounded theory. Here the researcher uses qualitative research with a case study approach because the research conducted covers a case in real life in a contemporary context or setting. Where according to Creswell (2015), case study research is a qualitative approach whose researchers explore real-life, contemporary limited systems (cases) or various limited systems (various causes), through detailed and indepth data collection involving various sources of information or sources of information compound (minutes, observations, interviews, audiovisual materials, and documents and various reports), and report case descriptions and case themes. The unit of analysis in a case study can be a compound case (multi-site study) or a single case (study on-site) "

This method is an effort to explore, describe, describe, record, analyze, interpret events, and facts found in research regarding the implementation of terminal Cicaheum management on the accessibility of prospective passengers.

The populations in this study were 40 UPTD officers and Bandung City Cicaheum terminal managers. The data collection techniques performed consisted of: Qualitative Observation, Qualitative Interviews, Qualitative Documents, Qualitative Audio and Visual Materials.

The variables of this study are the terminal management and accessibility variables. The researcher uses the dimensions of the management variables of Adisasmita and the accessibility dimensions of Fidel Miro as the instrument of his analysis knife.

There are several dimensions and indicators of management and accessibility that are subsequently by the dimension researchers, and these indicators are outlined in the form of several questions as a basis for guiding interviews with several informant sources. 
Vol.. 6, No. 1, 2020

Doi: https://doi.org/10.24198/cosmogov.v6i1.25736

http://jurnal.unpad.ac.id/cosmogov/index

Table 5. Operational Research Parameters

\begin{tabular}{|c|c|c|c|c|c|}
\hline Kajian & & Dimensi & & Indikator & Sumber \\
\hline 1 & & 2 & & 3 & 5 \\
\hline \multirow[t]{11}{*}{ Pengelolaan } & $\mathbf{1}$ & Perencanaan & 1 & Menyusun rencana kegiatan & Dokumen \\
\hline & & & 2 & Merumuskan kegiatan & Wawancara \\
\hline & & & 3 & $\begin{array}{l}\text { Mengidentifikasi kemudahan dan } \\
\text { hambatan }\end{array}$ & Observasi \\
\hline & & & 4 & Mengembangkan kegiatan & \\
\hline & 2 & Pelaksanaan & 1 & Melaksanakan tugas dan fungsi & \\
\hline & & & 2 & Merinci kegiatan & \\
\hline & & & 3 & $\begin{array}{l}\text { Pembagian wewenang dan } \\
\text { tanggungjawab }\end{array}$ & \\
\hline & & & 4 & $\begin{array}{l}\text { Terlaksananya sistem pengaturan } \\
\text { dan penertiban bis }\end{array}$ & \\
\hline & & & 5 & standar terpenuhi & \\
\hline & 3 & Pengawasan & 1 & pengawasan operasional & \\
\hline & & & 2 & Laporan Kinerja & \\
\hline \multirow[t]{4}{*}{ Aksesibilitas } & $\mathbf{1}$ & Faktor waktu tempuh. & 1 & $\begin{array}{l}\text { indikator ketersediaannya } \\
\text { prasarana transportasi dan sarana } \\
\text { transportasi yang dihandalkan. }\end{array}$ & $\begin{array}{l}\text { Dokumen, } \\
\text { Wawancara, } \\
\text { Observasi }\end{array}$ \\
\hline & 2 & $\begin{array}{l}\text { Faktor biaya/ongkos } \\
\text { perjalanan }\end{array}$ & 2 & $\begin{array}{l}\text { biaya perjalanan ikut berperan } \\
\text { dalam menentukan mudah tidaknya } \\
\text { tempat tujuan dicapai }\end{array}$ & \\
\hline & 3 & $\begin{array}{l}\text { Faktor intensitas } \\
\text { (kepadatan) guna } \\
\text { lahan }\end{array}$ & 3 & $\begin{array}{l}\text { padatnya kegiatan pada suatu petak } \\
\text { lahan }\end{array}$ & \\
\hline & 4 & $\begin{array}{l}\text { Faktor pendapatan } \\
\text { orang yang melakukan } \\
\text { perjalanan }\end{array}$ & 4 & $\begin{array}{l}\text { faktor pendapatan orang yang } \\
\text { melakukan perjalanan }\end{array}$ & \\
\hline
\end{tabular}

The data analysis itself is carried out in several stages. According to Creswell (2016), there are 6 steps of data analysis in qualitative research, namely:

1. Process and prepare data for analysis

2. Read the entire data

3. Start coding all data

4. Apply the coding process to describe the settings (domains), people (participants), categories, and themes to be analyzed.

5. Show how these descriptions and themes will be restated in a qualitative narrative/report.

6. Making interpretations in qualitative research or interpreting data.

\section{RESULT AND DISCUSSION Terminal Management for Passenger Accessibility}

The results of the research and discussion of the researchers began with its refinement of affairs which became the authority of the central government, provincial and district/city governments. As it is known that Law Number: 32 of 2014 concerning Regional Government has expired because Law No. 23 of 2014 concerning Regional Government has been enacted.

There is a fundamental change between the old and new laws, especially regarding functions that are the authority, formerly regulated in a Government Regulation, in this case, Government Regulation No. 38/2007 concerning Division of Government Affairs between the Government, Provincial Governments, and Regency / Municipal Governments. At present, the affairs which become the 
Vol.. 6, No. 1, 2020

Doi: https://doi.org/10.24198/cosmogov.v6i1.25736

http://jurnal.unpad.ac.id/cosmogov/index

authority have been listed in the attachment to Law Number: 23 of 2014. The following can be seen in the division of Government Affairs in the Transportation Sector.

Table 6. Sub Affairs LLLAJ Affairs in Transportation

\begin{tabular}{ccccc}
\hline No & Sub Affairs & $\begin{array}{c}\text { Central } \\
\text { Government }\end{array}$ & $\begin{array}{c}\text { Province } \\
\text { Government }\end{array}$ & $\begin{array}{c}\text { Regency/City } \\
\text { Government }\end{array}$ \\
\hline 1 & $\begin{array}{l}\text { Traffic and Road Transport } \\
\text { (LLAJ) }\end{array}$ & $\begin{array}{c}\text { Management of } \\
\text { passenger } \\
\text { terminal type A }\end{array}$ & $\begin{array}{c}\text { Management of } \\
\text { passenger } \\
\text { terminal type B }\end{array}$ & $\begin{array}{c}\text { Management of } \\
\text { passenger } \\
\text { terminal type C }\end{array}$ \\
\hline
\end{tabular}

Source: Law No. 23 of 2014

A very influential change to the research topic of researchers in the implementation of transportation affairs. The old law for terminal management is the authority of regency/city-regional government, the new law for terminal type A that serves inter-provincial routes is the authority of the government (central), terminal type B that serves routes between regencies/cities is the authority of provincial government, and type $\mathrm{C}$ terminals that serve between cities and or between villages within cities are the authority of the regency/city government. Thus the term Cicaheum is now the authority of the central government.

Based on this phenomenon it is certainly very interesting when it becomes a research topic because after all changes to the law will certainly have an impact on the implementation of policies. Changes at this time are very principle because so far the management of terminals of all types is the authority of the district/city-regional government which is changed to the authority of the central and provincial governments. Of course, it is not easy there are several principles that must be prepared both Personnel, Financing, Facilities and Infrastructure and Documents (P3D).

\section{Terminal Management}

According to Adisasmita, there are three dimensions in management, namely: planning, implementation, supervision. From several dimensions and indicators the researcher compiled several questions with the following results:

First, the planning dimension. Informant sources from the elements of the Financial Management Agency and the regional assets of the City of Bandung conveyed a number of plans related to the Integrated Gedebage Terminal, Leuwi Panjang Terminal and Cicaheum Terminal which have now become Regional Programs, namely:

1. Terminal Type A in Bandung City is planned to be built in Gedebage covering an area of $8 \mathrm{Ha}$ and developed into an integrated area as a Transit Oriented Development (TOD) and Multimodal Terminal as stipulated in Regional Regulation No. 10 of 2015 concerning the Detailed Spatial Plan for Bandung City.

2. Existing Type A Terminals in Leuwi Panjang and Cicaheum Terminals are proposed to be the location of TOO with status as Type $\mathrm{C}$ and Government support 
Vol.. 6, No. 1, 2020

Doi: https://doi.org/10.24198/cosmogov.v6i1.25736

http://jurnal.unpad.ac.id/cosmogov/index

for the Corridor I Light Rapid Transit (LRT) investment project from Babakan Siliwangi-Leuwi Panjang along $10.147 \mathrm{Km}$. So that in the future planning services only serve the city's public transportation operations such as LRT (Light Rapid Transit), cable car, Bandung Metro Trans, city transportation and bike-sharing.

The above plan becomes invalid because the current terminal management is no longer the authority of the Bandung City Government, but it is already the central authority. In its implementation, it will certainly face a variety of special problems relating to the administration at large. One of the administrations that must be taken is the transfer of assets that had been owned by the Bandung City Government must be handed over to the new authority.

Programs and activities, especially at the UPT Terminal in 2019 especially the Cicaheum terminal, received a budget allocation of Rp. 690,000,000, - which is intended for rehabilitation and maintenance of terminals and activities to create discipline and maintenance of cleanliness in the terminal environment.

Tabel 7. Budget Allocation for Cicaheum Terminal

\begin{tabular}{|c|c|c|c|}
\hline No & Description & The budget (Rp) & Information \\
\hline 1 & Locally-Generated Revenue (PAD) & & \multirow{4}{*}{ Change } \\
\hline 2 & Maintenance & 5.000 .000 & \\
\hline 3 & HR & 630.000 .000 & \\
\hline 4 & Cleaning tool & 55.000 .000 & \\
\hline & Total & 690.000 .000 & \\
\hline & Deficit & $(33.534 .500)$ & \\
\hline
\end{tabular}

Because the Cicaheum terminal types A, the Bandung City Government has no longer budgeted for maintenance but has shifted to work in the form of painting the terminal and installing a sink for the health post of Rp. 5 million.

Second, the implementation dimension. At the level of implementation of the transition of the implementation of Law Number: 23 of 2014, the Ministry of Transportation Republic of Indonesia Number: 132 of 2015 has been stipulated concerning the Implementation of the Road Transport Passenger Terminal as a legal umbrella.

Constraints felt during the transition to the transfer of authority function until the third year from the end of December 2016 have not yet been carried out the transfer of functions of Personnel, Financing, Facilities and Infrastructure and Documents (P3D).

This certainly has an impact on programs and activities that have so far become the authority of the region, with these changes, of course, the Bandung City Transportation Department cannot run optimally in carrying out its duties and functions, particularly the terminology management of Cicaheum which belongs to type A.

The findings of researchers in the management of assets whose assets are essentially the property of the state, but in 
Vol.. 6, No. 1, 2020

Doi: https://doi.org/10.24198/cosmogov.v6i1.25736 http://jurnal.unpad.ac.id/cosmogov/index

reality, especially those who have assets do not simply hand over. This has been proven so far that the 2 types A terminals owned by the Bandung City Government, namely the Leuwipanjang terminal and the Cicaheum terminal, the asset handover have not been implemented. The protracted time will, of course, face a major problem that downstream community services, especially direct transport services will not be disrupted. The way out is to continue to carry out programs and activities in accordance with the duties and functions based on regional authority, namely, type $\mathrm{C}$ terminals located in the Cicaheum terminal location.

Third, the supervision dimension, the officer regularly carries out operational oversight of administrative completeness including the applicable SIM and STNK, route licenses, and test marks of public motor vehicles. Data on public motor vehicles have baseline data, making it easier for officers to carry out their supervision. Vehicle physical supervision As with administrative oversight, it is carried out periodically when entering and exiting the terminal. The officer inspects the vehicle physically to identify whether or not the vehicle is travelling according to the designated route.

vehicle crew supervision Staff always supervise vehicle crews especially driver bus driver stamina. At a certain time, we collaborate with the Bandung City
Health Office to check all bus crews to monitor the physical readiness of the bus crews. Performance Reports in accordance with statutory regulations, performance reports are made every month, quarterly and annually. There are several reports made, among others, the UPT Terminal performance report, the Office Performance Report in the form of LAKIP, and the Bandung City Government LKPJ.

\section{Passenger Accessibility}

Passenger variable is the causal effect of terminal management, the better the terminal management, the more comfortable is felt by the passenger. According to Fidel Miro, there are four factors that affect the level of accessibility, namely the travel time factor, the cost/travel cost factor, the intensity factor (density) of land use, the income factor. From several dimensions and indicators the researcher compiled several questions with the following results:

First, the dimension of the travel time factors. Availability of transportation to and from the Cicaheum terminal is adequate and has been connected to both public transport and large public buses which are relatively far away that connect between regions in the city of Bandung. The following can be seen the connection lines between regions within the city of Bandung with city transportation.

Table 8. Number of Fleet and Length of Public Transportation Routes

\begin{tabular}{clcc}
\hline No & \multicolumn{1}{c}{ Route Trajectory } & $\begin{array}{c}\text { Distance } \\
(\mathbf{K m})\end{array}$ & $\begin{array}{c}\text { Amount of } \\
\text { Allocation }\end{array}$ \\
\hline 1 & Abdul Muis - Cicaheum Via Binong & 16,30 & 355 \\
2 & Abdul Muis - Cicaheum Via Aceh & 11,55 & 100 \\
3 & Abdul Muis - Dago & 9,30 & 271
\end{tabular}


Vol.. 6, No. 1, 2020

Doi: https://doi.org/10.24198/cosmogov.v6i1.25736

http://jurnal.unpad.ac.id/cosmogov/index

\begin{tabular}{clcc}
4 & Abdul Muis - Ledeng & 16,00 & 245 \\
5 & Abdul Muis - Elang & 9,75 & 101 \\
6 & Cicaheum - Ledeng & 14,25 & 214 \\
7 & Cicaheum - Ciroyom & 17,00 & 206 \\
8 & Cicaheum - Ciwastra - Derwati & 17,00 & 200 \\
9 & Cicaheum - Cibaduyut & 16,10 & 150 \\
10 & St.Hall - Dago & 10,00 & 52 \\
11 & St.Hall - Sadang Serang & 11,00 & 150 \\
12 & Hall - Ciumbuleuit (via Eyoman) & 9,80 & 52 \\
13 & St.Hall - Ciumbuleuit (via Cihampelas) & 8,30 & 30 \\
14 & St.Hall - Gede Bage & 21,00 & 200 \\
15 & St.Hall - Sarijadi & 10,20 & 80 \\
16 & St.Hall - Gunung Batu & 8,50 & 53 \\
17 & Margahayu Raya - Ledeng & 19,80 & 125 \\
18 & Dago - Riung Bandung & 20,60 & 201 \\
19 & Pasar Induk Caringin - Dago & 19,85 & 140 \\
20 & Panghegar Permai - Dipatiukur & 19,35 & 155 \\
21 & Ciroyom - Sarijadi & 11,75 & 88 \\
22 & Ciroyom - Bumi Asri & 8,35 & 115 \\
23 & Ciroyom - Cikudapateuh & 12,90 & 140 \\
24 & Sederhana - Cipagalo & 16,05 & 276 \\
25 & Sederhana - Cijerah & 8,90 & 63 \\
26 & Sederhana - Cimindi & 9,00 & 55 \\
27 & Ciwastra - Ujung Berung & 13,40 & 32 \\
28 & Cisitu - Tegallega & 13,95 & 82 \\
29 & Cijerah - Ciwastra - Derwati & 22,30 & 200 \\
30 & Elang - Gedebage - Ujung Berung & 22,45 & 115 \\
31 & Abdul Muis - Mengger & 10,55 & 25 \\
32 & Cicadas - Elang & 18,05 & 300 \\
33 & Antapani - Ciroyom & 13,70 & 160 \\
34 & Cicadas - Cibiru - Panyileukan & 13,65 & 200 \\
35 & Bumi Panyileukan - Sekemirung & 24,35 & 125 \\
36 & Sadang Serang - Caringin & 18,10 & 200 \\
37 & Cibaduyut - Karangsetra & 16,60 & 201 \\
38 & Cibogo Atas - Elang & 7,00 & 32 \\
39 & Ciroyom - Sarijadi Via Setrasari & 10,75 & 31 \\
\hline & & & \\
& & & \\
\hline
\end{tabular}

Source: Bandung City Transportation Agency, 2019

In addition to city transportation, east-west, east-south and east-city centre. there are also trajectories that the bus fleet This can be seen in the table below: connects between the regions east-north,

Table 19. Number of City Bus Fleets

\begin{tabular}{clcc}
\hline No & \multicolumn{1}{c}{ Route Trajectory } & $\begin{array}{c}\text { Transportation } \\
\text { Type }\end{array}$ & Amount \\
\hline 1 & Cicaheum - Cibeureum & Bis Besar & 36 \\
2 & Ledeng - Leuwipanjang & Bis Besar & 18 \\
3 & Leuwipanjang - Dipatiukur & Bis Besar & 11 \\
4 & Leuwipanjang - Cicaheum & Bis Besar & 37 \\
5 & Cibiru - Kebon Kelapa & Bis Besar & 24 \\
& & & 126 \\
\hline
\end{tabular}

Source: Bandung City Transportation Agency, 2019 
Vol.. 6, No. 1, 2020

Doi: https://doi.org/10.24198/cosmogov.v6i1.25736

http://jurnal.unpad.ac.id/cosmogov/index

Dimensions of the cost/fare factors, which determination of the tariff is set by the Decree of the Minister of Transportation based on the class of vehicles, distance travelled and the bus facilities used. One of the Minister's Decrees is the Minister of Transportation's Decree Number: KM. 89 of 2002 concerning the Mechanism of the Determination of Tariffs and the Formula for Calculating the Cost of Passenger Transportation by Public Inter-City Class Bus Cars. Here are some bus fares based on bus names and routes between City/District and Province.

Tabel 10. Bus Fares From Cicaheum To Between City / Region / Province

\begin{tabular}{|c|c|c|c|}
\hline$\overline{\text { No }}$ & Bus & Destination & $\begin{array}{c}\text { Rates } \\
(\mathbf{K}=\mathbf{R p})\end{array}$ \\
\hline 1 & Bintang Sanepa & Hariang (Sumedang) & $30-39$ \\
\hline 2 & Bhineka & Cirebon & $55-65$ \\
\hline 3 & Bhineka Sangkuriang & Cirebon & $100-130$ \\
\hline 4 & Sahabat & Cirebon & $55-75$ \\
\hline 5 & Dina Prima & Singaparna & $40-50$ \\
\hline 6 & Mulyasari & Toblong (Tasikmalaya) & $60-80$ \\
\hline 7 & Budiman & Tasikmalaya & $45-58$ \\
\hline 8 & Budiman & Pangandaran & $65-84,80-104$ \\
\hline 9 & Damri & Indramayu & $60-65$ \\
\hline 10 & Damri & Kuningan & $65-70$ \\
\hline 11 & Madona & Purwokerto & $85-110$ \\
\hline 12 & Bejeu & Kudus & 175-195 \\
\hline 13 & Mandala (Handoyo Group) & Surabaya & $180-200$ \\
\hline 14 & Sugeng Rahayu Cepat & Surabaya & $225-255$ \\
\hline
\end{tabular}

Source: https://jadwalbis.com, 2019

Dimensions of the intensity factor (density) of land use. Dense activity on a plot of land. It is already inadequate, especially at this time the Cicaheum terminal which has the title of type A terminal has lagged far behind the mandate of legislation as a legal basis both governing the operation of the road transport passenger terminal, as well as the Standard of Service and Operations of the Road Transport Passenger Terminal.

Standard passenger terminal services at the road transport passenger terminal must be provided and implemented by the terminal operator

1. Health servant

2. Security services
3. Reliability service

4. Comfort service

5. Ease/affordability services

6. Equality services

There are several requirements that must be met in determining the terminal including the location of the passenger terminal must be located at the node of the traffic network and road transportation intended for the change of intermodal and/or intermodal in an area.

Determination of the location of the passenger terminal must pay attention to:

1. The level of accessibility of users of transport services 
Vol.. 6, No. 1, 2020

Doi: https://doi.org/10.24198/cosmogov.v6i1.25736

http://jurnal.unpad.ac.id/cosmogov/index

2. Land suitability with national RTRW, Provincial RTRW, Regency / City RTRW.

3. Land suitability with development plans and / or road network and route network performance.

4. Compliance with development plans and/or activity centres.

5. Harmony and balance with other activities.

6. Request for transport.

7. Technical, financial, and economic feasibility.

8. Security and safety of traffic and road transportation; and

9. Sustainability of environmental functions

The income factor dimension. Grouping of passengers based on social status factors of income of people who travel. Based on the results of interviews and observations of researchers that passenger stratification was identified to the SME (Micro Small Business) entrepreneurial group, a small portion of the middle class, students, and employees.

\section{CONCLUSION}

The transition of authority, Cicaheum terminal is a Type A terminal because it serves between Provinces, formerly the authority of the Regency / City. Since the enactment of Law Number 23 the Year 2014 concerning Regional Government, the management of Type A terminal authority has become the authority of the Center.

The transition of authority is already in its third year, the transfer of Personnel, Funding, Facilities and
Infrastructure, and Documents (P3D) has not yet been implemented. Based on the Regulation of the Minister of Transportation Number PM 132 the Year 2015 Concerning the Operation of the Road Transportation Passenger Terminal. In Chapter XIII Transitional Provisions Article 57 The implementation of type A and $B$ terminals will continue to be carried out by Regency / City until the submission of Personnel, Funding, Facilities and Infrastructure, and Documents (P3D) for the holding of type A terminals from the Regency / City government to the Minister and type B terminals from Regency / City government to the Governor no later than 31 December 2016.

Delay in the transfer of authority will certainly have an impact on community services, especially services in the field of transportation, especially the sub-affairs of Traffic and Road Transportation (LLAJ). One of the research findings since the 2019 Budget Year Bandung City Government through the Department of Transportation has no longer allocated the Cicaheum terminal budget. How could an organization run without a budget?

In the Organizational Legal Arrangement, there are many stages to be carried out, this will have implications for Personnel, Financing, Facilities and Infrastructure and Documents (P3D). P3D is a keyword in policy implementation. The policy cannot be implemented immediately if the P3D element has not yet carried out the transfer of authority. In addition, the operation of road transport terminals, Service Standards and the Implementation 
Vol.. 6, No. 1, 2020

Doi: https://doi.org/10.24198/cosmogov.v6i1.25736

http://jurnal.unpad.ac.id/cosmogov/index

of Road Transport Passenger Terminals, management by itself cannot be carried out. Terminal management has had an impact on passenger accessibility. Theoretically, the implementation of terminal management has not been fully implemented based on the management dimension. Empirically it can be seen that the terminal management variable implemented at the Cicaheum terminal has an impact on passenger accessibility, thus managing the terminal on passenger accessibility must always be improved.

\section{REFERENCES}

Adisasmita, R. (2011). Pengelolaan Pendapatan dan Anggaran Daerah. Yogyakarta: Graha Ilmu.

Agustino, L. (2006). Politik \& Kebijakan Publik. Bandung: AIPI Bandung.

Gultom, C. B. (2014). Pengelolaan Terminal Bandar Rava Payung Sekaki Oleh Unit Pelaksana Teknis Dinas (Uptd) Terminal Dinas Perhubungan Komunikasi dan Informasi Kota Pekanbaru. Jurnal Online Mahasiswa (JOM) Bidang Ilmu Sosial dan Ilmu Politik, 1(2), $1-11$.

Creswell, J. W. (2015). Penelitian Kualitatif Dan Desain Riset. Yogjakarta: Pustaka Pelajar.

Decree of the Minister of Transportation Number 31 of 1995 concerning Road Transportation Terminals.

Fahmi, I. (2015). Manajemen Kinerja: Teori dan Aplikasi. Bandung: Alfabeta.

Ikhsan, M. (2016). Pengaruh Akseptabilitas, Afordabilitas, Aksesibilitas dan Kesadaran Terhadap Niat Beli Lavanan $4 G$ Telkomsel di Bandar Lampung (Doctoral dissertation, Tesis. Universitas Lampung. Bandar Lampung).

Iskandar, J. (2013). Metode Penelitian Administrasi. Bandung: Puspaga

Keban, Y. T. (2004). Enam Dimensi Strategik Administrasi Publik. Yogyakarta: Gava Media.
Meiliati, D. (2016). Analisis Pengelolaan Terminal Bandar Laksmana Indragiri Oleh Dinas Perhubungan Kabupaten Indragiri Hilir (Doctoral dissertation, Universitas Islam Negeri Sultan Syarif Kasim Riau).

Miro, F. (2009). Perencanaan Transportasi bagi Mahasiswa, Perencana dan Praktisi. Jakarta: Erlangga.

Mukarom, Z., \& Laksana, M. W. (2015). Manajemen Pelayanan Publik. Bandung: Pustaka Setia.

Nugroho, R. (2003). Public Policy: Teori, Manajemen, Dinamika, Analisis, Konvergensi, dan Kimia Kebijakan. Jakarta: Elex Media Komputindo.

Pulungan, J. S. (2013). Efisisensi Kerja Dalam Pekerjaan Rumah Tangga. Jakarta: Kencana.

Peraturan Menteri Perhubungan Nomor 132 Tahun 2015 tentang Penyelenggaraan Terminal Penumpang Angkutan Jalan.

Purba, D. (2008). Analisis Prioritas FaktorFaktor Yang Mempengaruhi Efektivitas Fungsi Terminal Sarantama (Study Kasus Terminal Sarantama Kota Pematang Siantar) (Master's Thesis, Universitas Sumatera Utara Medan).

Rahmah, N. D. (2015). Forecasting Lalu Lintas Penumpang dan Perencanaan Terminal Building Bandar Udara Tijlik Riwut Kota Palangka Rava 20 Tahun yang Akan Datang. Palangka Rava: Universitas Muhammadiyah Palangka Raya.

Ridwan, H. R. (2011). Hukum Administrasi Negara. Jakarta: Raja Grafinfo Persada.

Siagian, S. P. (2014). Filsafat Administrasi. Jakarta: Bumi Aksara.

Silalahi, U. 2012. Metode Penelitian Sosial. Bandung: Refika Aditama.

Sugiyono. (2011). Metode Penelitian Administrasi. Bandung: Alfabeta.

Suparman, N. (2017). Kualitas Pelayanan Izin Mendirikan Bangunan (IMB) Pada Badan Pelayanan Perizinan 
Vol.. 6, No. 1, 2020

Doi: https://doi.org/10.24198/cosmogov.v6i1.25736

http://jurnal.unpad.ac.id/cosmogov/index

Terpadu Dan Penanaman Modal (BPPTPM) Kabupaten Cianjur Provinsi Jawa Barat. Jurnal Borneo Administrator, 13(1).

Tamim, O. Z. (2000). Perencanaan dan Permodelan Transportasi. Bandung: Penerbit ITB.

Ukas, M. (2004). Manajemen: Konsep, Prinsip dan Aplikasi. Bandung: Agnini Bandung.

Konda, V., \& Gosal, P. H. (2017). Pengaruh Lavanan Terminal Bolu di Kecamatan Tallunglipu
Terhadap Pertumbuhanwilavah Kabupaten Toraja Utara. SPASIAL, 4(1), 67-78.

Wahab, S. A. (2012). Analisis Kebijakan: Dari Formulasi ke Model-Model Implementasi Kebijakan Publik. Jakarta: Bumi Aksara

Widodo, J. (2011). Analisis Kebijakan Publik: Konsep dan Aplikasi, Analisis Proses Kebijakan Publik. Malang: Bayumedia Publishing. 